\title{
Performance Investigation of Flat Plate and Evacuated Tube Collectors under Jordan Climate Conditions Using TRNSYS Software
}

\author{
Mohammed Al-Odat ${ }^{*}$, Khalida Rawashedsh ${ }^{1}$, Mohammed Al-Hasan ${ }^{2}$ \\ ${ }^{1}$ Department of Mechanical Engineering, Al-Huson University College, Al-Balqa Applied University, P.O. Box: 50 Al-Huson \\ 21510, Jordan \\ ${ }^{2}$ Department of Mechanical Engineering, Faculty of Engineering Technology, Al-Balqa Applied University, P.O. Box: 15008 \\ Amman 11134, Jordan \\ Corresponding Author Email: m.odat@ bau.edu.jo
}

https://doi.org/10.18280/mmep.080118

Received: 15 October 2020

Accepted: 23 December 2020

\section{Keywords:}

flat plate collectors, evacuated tube collectors, TRNSYS-16 software, thermal efficiency, useful energy gain

\begin{abstract}
The performance of the Flat Plate Collector (FPC) and Evacuated Tube Collector (ETC) for domestic hot water applications under Jordan climate conditions was theoretically investigated using TRNSYS software. The presented simulation model can provide a long-term evaluation of system performance at different weather conditions. This simulation was carried out during 24 hours in 21 June, is considered as a hot climate and 21 January is considered as a cold climate; under the meteorological conditions of both Irbid and Aqaba cities in Jordan. The inlet water temperature of the first collector, collector area, water flow rate and tilt angle were considered $15^{\circ} \mathrm{C}, 2.04 \mathrm{~m}^{2}, 0.0139 \mathrm{~kg} / \mathrm{s}$ and 45 degrees respectively. The outlet temperature of each collector was considered as the inlet of the previous collector. Three collectors in series were applied to increase the output temperature up to $90-100^{\circ} \mathrm{C}$. The results showed that $\mathrm{TE}$ increased with the decrease in the inlet temperature, which means the useful energy gain $\left(\mathrm{Q}_{\mathrm{u}}\right)$ of the first collector is greater than the $2^{\text {nd }}$ and the $3^{\text {rd }}$ collector. The useful energy gain $\left(\mathrm{Q}_{\mathrm{u}}\right)$ of ETC is greater than of FPC, and the useful energy gain $\left(\mathrm{Q}_{\mathrm{u}}\right)$ of cold climate is less than hot climate. The output temperature of ETCs is greater than that of FPCs for Irbid city in cold and hot climate. Furthermore, for Aqaba in cold climate and in hot climate the outlet temperature of ETCs is higher than FPCs. Additionally, the daily thermal performance of the ETCs is significantly better than the FPCs in cold climate. Meanwhile, thermal performance of both collectors are close in a hot climate.
\end{abstract}

\section{INTRODUCTION}

Thermal solar energy is produced by converting sunlight into heat. Thermal collectors implement to collect solar energy to heat water; their main types are the flat plate collectors (FPC) and evacuated tube collectors (ETC). The act of both types is based on climate conditions and absorber characteristics. The absorber is flat and incorporates tubes, receives the solar radiation and transfer the heat to water which circulates within the tubes [1]. The ETC designed as a singlephase open thermosyphon (SPOT) or two-phase closed thermosyphon (TPCT), their pipes are insulated. Both are worked with the natural $[2,3]$ or enforced flow by using the pump [4] in domestic - scale applications [5-9]. The thermosyphon flow designed for SPOT consists of two concentric tubes (borosilicate glass) with a small space [5, 8]. The inner space between the two pipes is evacuated that which leads to decrease convection heat losses and improves efficiency. The outside of the inner tube is carried out with a special black coating to increase the rate of absorption and decreases the heat losses [10]. Evacuated tubes provide greater daily heat output as a result of the shape of cylindrical absorber which is perpendicular to the radiation of solar. The cold water passes within the inner tube and absorbs the heat then becomes hot and flows up subsequently this is displaced by cold water inflow from a storage tank.
The TPCT consists of a tube of borosilicate glass and another metallic tube (typically copper), both are sealed. The working fluid flows within the metallic tube. The metallic tube consists of two sections; the lower section is an evaporator and the upper section is a condenser. the working fluid vaporizes and rises to the upper section and replaced the cold fluid, the vapor in the upper section, after a very short resident time, condenses then falls in the liquid pool at the lower section due to gravity. The water in the storage tank absorbs released the latent heat which is released during the condensing process.

Perers [11] carried out a comparison of performance for FPCs and ETC, he concluded that the best performance has produced near $400 \mathrm{kWh} /\left(\mathrm{m}^{2}\right.$ year) by ETC and $300 \mathrm{kWh} / \mathrm{m}^{2}$ by FPC at a temperature of $60 \mathrm{C}$. Morrison et al. [12] investigated the performance of both collectors and found that ETC has higher efficiency than FPC at temperatures above $100^{\circ} \mathrm{C}$. The FPCs depended on two essentials: A black absorbing, transport medium (fluid tubes) that welded or integrated to the absorbing plate and a glass cover uses to prevent heat losses [13]. The FPC can either glazed or unglazed, the glazed type has a glass cover above the absorber that suitable for applications up to $70^{\circ} \mathrm{C}$. While the unglazed collector has an absorber without cover that suitable for the low-temperature applications. The black plat absorbs the solar radiation and transports the heat to a fluid that passes in tubes; the fluid carried the heat to a storage tank. The underside of 
the system is isolated to reduce conduction losses. The tubes are connected at two ends by large-diameter header tubes which are connected with a collector $[14,15]$.

The performance of FPCs and ETCs were studied and the study showed that both collectors are considered to be convenient for solar heating [13]. Struckmann [14] created a mathematical model to simulate the performance and the overall heat loss coefficient and other parameters of the FPCs system and reported that the heat removal factors are not constant values. Duck et al. [15] analyzed the performance, financial and environmental issues for many collectors with different areas and types, they founded that ETC has the highest performance and the lowest energy payback period of 1.3 year. The performance of flat plate collectors (FPC) and evacuated tube collectors (ETC under Palestine climate condition was experimentally studied [16]. Ayompe et al. [17] reported that FPC with the area of $4 \mathrm{~m}^{2}$ stands quite higher than ETC with the area of $3 \mathrm{~m}^{2}$ when joined to a $300 \mathrm{~L}$ hot fluid tank, the study was implemented in Dublin, Ireland. Kong et al. [18] evaluated the performance of FPC and ETC in two scales domestics and industrial scale for two areas with a hot and cold climate in Iran; they used TRNSYS software to simulate the behavior of both collectors. They concluded that the improved function approach can precisely and strongly evaluate these collectors.

Kasaeian et al. [19] analyzed the annual efficiency and solar fraction in ETC using TRANSYS in Tehran. Their results showed that the simulated and experimental tests are closed together and those suffering are 50-60\%. Remlaoui et al. [20] presented simulated and modeled combined FPC desalination system by using commercial code TRNSYS, they optimized a complete simulation of (Contact Membrane Distillation) DCMD- FPC. Tang et al. [21] carried out the performance of single-phase ETC with varies tilt angles, their results showed that the daily efficiency of inclined $\mathrm{SWH}$ at $46^{\circ} \mathrm{C}$ is similar to that of inclined SWH at $22^{\circ} \mathrm{C}$. Tang et al. $[12,13]$ expressed the modern mathematical approach to find the optimal choice of tilt and zenith angle. Tang et al. [22] reported that the thermal performance of water-in-glass SDHWS is independent of the slope of a collector.

Recently, Kumar et al. [23] carried a comprehensive review of experimental and numerical studies and the latest developments regarding the investigation of evacuated tube solar collectors. Siuta-Olcha et al. [24] carried an experimental study on the energy performance of an evacuated solar collector, heat pipe type, consisting of 24 tubes, over the period of 2 months under Lublin (Poland) climate conditions. They investigated the effect of the weather conditions and operating parameters on the thermal performance of the evacuated tube solar collector. Olczak et al. [25] carried out a comparison study of solar energy gaining effectiveness between flat plate collectors and evacuated tube collectors with heat pipe. Greco et al. [26] carried out a comparison study TRNSYS software, using of the energy performances of flatplate collectors (fpcs) and evacuated-tube collectors (etcs) in domestic solar water heating systems located in different climate areas Their Investigations were carried out on single fpcs and etcs and also for strings of four panels connected in series.

Bases on the previous literature review it was found there is no any reported study considering the comparison between the thermal performance of FPC and ETC under Jordan climate conditions. Therefor the main objective of the present study is to carry out a compassion study on the thermal Performance of flat-plate and evacuated tube collectors for solar water heating systems under Jordan climate conditions. Two different climates were considered in this research work, one in the Irbid city which represent the Mediterranean Climate Conditions and the other is Aqaba which represents the hot and moist climate conditions. For both cities the performance under hot and cold climate is reported.

\section{METHODOLOGY}

\subsection{Site description}

Jordan is suitable for utilizing STES due to its location close to the equator. The average sunny days of Jordan are around 310 days a year. The average solar radiation varies from 4 $\mathrm{KWh} / \mathrm{m}^{2}$ in June and $8 \mathrm{KWh} / \mathrm{m}^{2}$ in June, which has a potential of $1400-2300 \mathrm{GWh} /$ year [27].

In the investigation study of the solar thermal energy system (STES), we chose two cities in Jordan, these cities are Irbid and Aqaba city. The Irbid city is located in the north of Jordan which is characterized by a moderate - cold climate. The latitude, longitude, and elevation of the Irbid city are $32^{\circ} 33^{\prime} 20^{\prime \prime} \mathrm{N}, 35^{\circ} 51^{\prime} 00^{\prime \prime}$, E and $570, \mathrm{~m}=1870 \mathrm{ft}$, respectively. The average mean air temperature of Irbid in the ranges of $10^{\circ} \mathrm{C}$ in January $-26.2^{\circ} \mathrm{C}$ in June and the average mean earth temperature in the ranges of $11.3^{\circ} \mathrm{C}$ in January $-34.2^{\circ} \mathrm{C}$ in June. The average relative humidity was observed to be in Irbid at $72 \%$ in January and $51.7 \%$ in June. The average solar radiation varies from $2.49 \mathrm{~kW} / \mathrm{m}^{2} /$ day in January and $7.8 \mathrm{~kW} / \mathrm{m}^{2} /$ day in June $[28,29]$.

Aqaba city is located in the south of Jordan and its climate is hot. Aqaba city has an altitude of $39^{\circ} 54^{\prime} 26^{\prime \prime} \mathrm{N}$, the longitude of $116^{\circ} 23^{\prime} 50^{\prime \prime} \mathrm{E}$ and elevation above sea level of $49 \mathrm{~m}=160$ $\mathrm{ft}$. The average mean air temperature of Aqaba in the ranges of $15^{\circ} \mathrm{C}$ in January $-33.2^{\circ} \mathrm{C}$ in June and the average mean earth temperature in the ranges of $13.6^{\circ} \mathrm{C}$ in January $-32.7^{\circ} \mathrm{C}$ in June. The average relative humidity was observed to be in Irbid at $59 \%$ in January and $42.3 \%$ in June. The average solar radiation varies from $3.1 \mathrm{~kW} / \mathrm{m}^{2} /$ day in January and $8.35 \mathrm{~kW} / \mathrm{m}^{2} /$ day in June [28, 29]. The meteorological data for Irbid city and Aqaba city is an average value per 21 January and 21 June over a period of 24 hours, while the solar climatology data is an average over the previous period.

\subsection{Solar heating systems}

The system which is used to investigate the performance of collectors is an active system type (uses pump), we chose the direct circulation system where the water that is taken from a hot storage tank is the same that has circulated through the collector.

Evacuated tubes provide greater daily heat output a STES, four main components have an essential effect on the overall performance of the system. These components are hot water storage tank, control, solar collector, pump, and the load quantity.

\subsubsection{TRNSYS model}

Both FPC and ETC are modeled using TRNSYS. TRNSYS is a complete and expanded simulation environment for the transient system simulation, to investigate the industrial and domestic hot water systems to the design of the thermal systems and their equipment. 


\subsubsection{Meteorological data}

Type15 of Standard Format $\backslash$ TMY2 was used to read and process weather data of Irbid city and Aqaba city to calculate the solar radiation properties [30]. Where TMY2 files contain meteorological and radiation of solar for an area. The area was selected for Irbid city and Aqaba city because these cities present a moderate and hot climate in Jordan.

Type 15 is used to calculate the incident radiation and to set the azimuth of the tilted plane, also to set the surface slope (azimuth to 0 and surface slop to 45).

\subsubsection{Single phase ETC \& FPC}

The Type 1 Solar collector was selected to FPC with quadratic efficiency parameters. Type 71 was used to choose ETCs, according to single-phase ETC which chosen, the transport fluid (water) is circulated between the tubes and the storage tank. To achieve the heating demands on an industrial scale, three of the collectors were connected in series to satisfy the heating load. The input data of the collectors were introduced to the TRANSYS program; they are collected through a technical catalog. Other inputs to the model were selected from Type14b of the load profile such as the amount of consumption/ demands of hot water (per month, per daily, per hour). The input characteristics for both FPC and ETC are presented in Table 1.

\subsection{Pump}

The active system which was investigated included a pump. The main objective of the pump is to circulate the water from the solar collector to the storage tank which is operated by the control unit (on and off). Type $3 b$ (Hydronics $\backslash$ Pump $\backslash$ Single speed) is used to model the Pump Simple pump model (imposed flow rate). The pump operation was controlled according to the outlet temperature of the last collector and the storage tank temperature.

Table 1. Characteristics of FTP input to Type1b, TRANSYS16

\begin{tabular}{c|c|c}
\hline Parameter & Value & Unit \\
\hline Collector Area & 2.04 & $\mathrm{~m}^{2}$ \\
Weight (when empty) & 42 & $\mathrm{Kg}$ \\
Liquid capacity & 1.3 & $\mathrm{~L}$ \\
Efficiency Slope & 4.36 & $\mathrm{~W} / \mathrm{m}^{2} \mathrm{~K}$ \\
Efficiency curvature & 0.0049 & $\mathrm{~W} / \mathrm{m}^{2} \mathrm{~K}^{2}$ \\
Fluid Specific Heat & 4.190 & $\mathrm{KJ} / \mathrm{kg} . \mathrm{K}$ \\
Material of absorber sheet & Copper/Aluminum & \\
piping & $\mathbf{2}$ & $\mathbf{m}^{2}$ \\
Collector Area & $\mathbf{6 0}$ & $\mathbf{K g}$ \\
Weight (when empty) & $\mathbf{3 . 6}$ & $\mathbf{L}$ \\
Liquid capacity & $\mathbf{1 . 2 7}$ & $\mathbf{W} / \mathbf{m}^{2} \mathbf{K}$ \\
Efficiency Slope & $\mathbf{0 . 0 0 1 2}$ & $\mathbf{W} / \mathbf{m}^{2} \mathbf{K}^{2}$ \\
Efficiency curvature & $\mathbf{4 . 1 9 0}$ & $\mathbf{K J} / \mathbf{k g} \cdot \mathbf{K}$ \\
Fluid Specific Heat & $\mathbf{3}$ & $\mathbf{K g} / \mathbf{h r} \cdot \mathbf{m}^{2}$ \\
Tested Flow rate & Copper / Copper & \\
Material of absorber sheet & \\
piping & \multicolumn{2}{|l}{}
\end{tabular}

\subsection{Storage tank}

The solar energy collected during the sunny day (5-7 hours) transport to the storage tank by transport fluid via collectors. The hot water is used directly or needs to save in a storage tank and then it can be used at night or on a cloudy day. The storage tank is selected from Type $4 \mathrm{c}$. Table 2 shows the characteristics of the storage tank.

Table 2. Characteristics of Type4c (Storage Tank) in Trnsys16

\begin{tabular}{ccc}
\hline Parameter & Value & Units \\
\hline Volume Tank & $\mathrm{ETC}=0.06$ & $\mathrm{~m}^{3}$ \\
Fluid Specific Heat & $\mathrm{FPC}=0.35$ & $\mathrm{KJ} / \mathrm{kg} . \mathrm{K}$ \\
Fluid Density & 1000 & $\mathrm{Kg} / \mathrm{m}^{3}$ \\
Tank Loss Coefficient & 2.5 & $\mathrm{KJ} / \mathrm{hr}^{2} \mathrm{~m}^{2} . \mathrm{k}$ \\
Boiling Point & 100 & ${ }^{\circ} \mathrm{C}$ \\
Height Of nod & 0.1 & $\mathrm{M}$ \\
\hline
\end{tabular}

\subsection{Control unit}

Type $2 \mathrm{~b}$ (such as a thermostat) is adopted as a controller unit. The control decisions are based on the difference between the temperature of a water tank and the outlet temperature of the last collector. The differential controller (Type2b) controlled the pump operation by sensing the temperature difference; the pump will be operating when the temperature difference exceeds $15^{\circ} \mathrm{C}$.

\subsection{System connections}

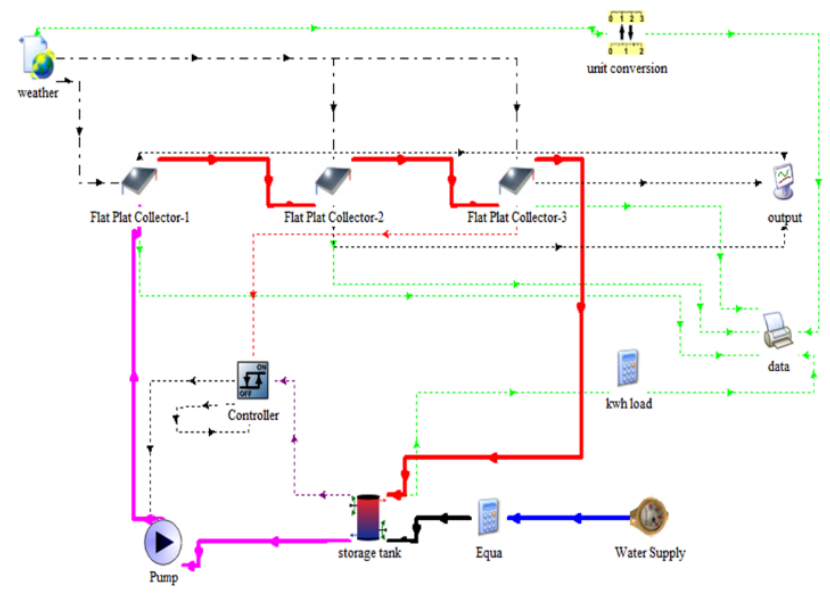

Figure 1. TRNSYS - FPC model

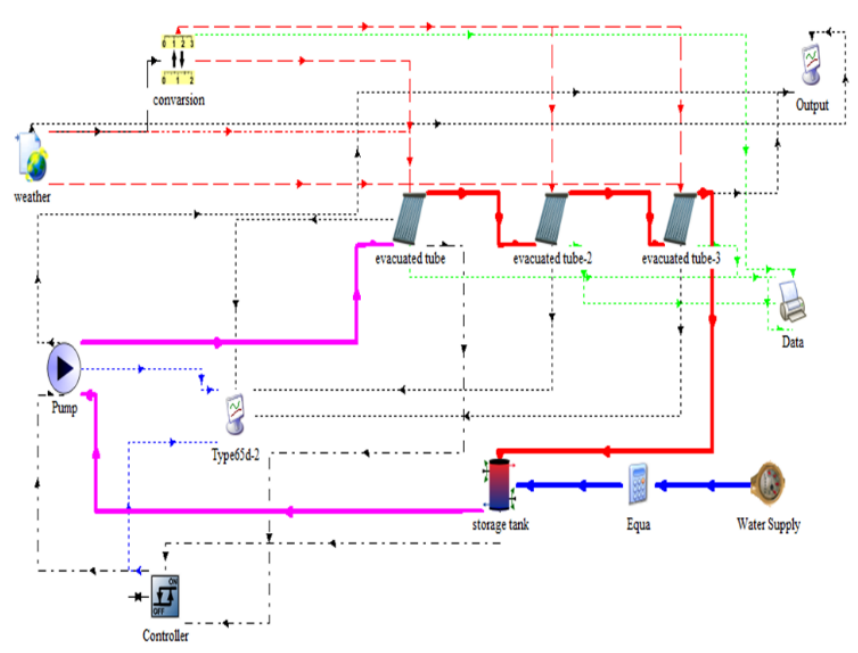

Figure 2. TRNSYS - ETC model

Each type of collector was used in separate models to investigate performance and efficiency. Components are 
connected using the Link tool, the outputs are connected to inputs as shown in Figures 1 and 2; Type15 (weather data) to collectors (Type1 or Type71), TMY2 to each collector, Type14 (forcing function) to Type 3b (pump), Type3 (outlet of the pump) to Type1 (first solar collector), the last solar collector to the storage tank, and the storage tank to pump.

Figure 1 shows the TRANSYS system model of the FPCs system, the system consists of three FPC in series, a control unit, a pump, a storage tank, and the load profile. Figure 2 shows the TRANSYS model of the ETCs system, which consists of three ETC in series, storage tank, pump, control unit, and load profile.

\section{RESULTS AND DISCUSSION}

The model investigation, which is conducted in Aqaba city and Irbid city, can be separated into two parts: FPC chosen to this investigation, based on a pre-study to find the optimal tilt angle $\left(22^{\circ}\right.$ for 21 Jan and $-22^{\circ}$ for 21 Jun model evaluation and ETC model evaluation for 24 hours (1 day) in the summer period and the winter period. Both models are compared in the terms of radiation, outlet temperature and useful energy gain.21 January and 21 June were) in a single day of the year.

For the investigation's comparison, the daily solar radiation on the tilted surfaces (collectors), the useful energy gain and the outlet temperatures were extracted by TRANSYS 16 . Furthermore, the efficiency of the collectors FPC and ETC were presented.

\subsection{Solar radiation yield}

Figure 3 shows the irradiation of the hot and cold climate of both Irbid and Aqaba city for 21 January and 21 June. As predicted, the irradiation of the hot in Irbid's climate is higher than Aqaba's climate due to the high humidity in Aqaba. While the irradiation of the cold climate in Irbid is lower than the yields in Aqaba. The highest value of received radiation was noted in mid-day (11:00 -13:00); however, the lowest yields were measured at sunrise and sunsets as shown in Figure 3. These results agreed with Hirsch [26].

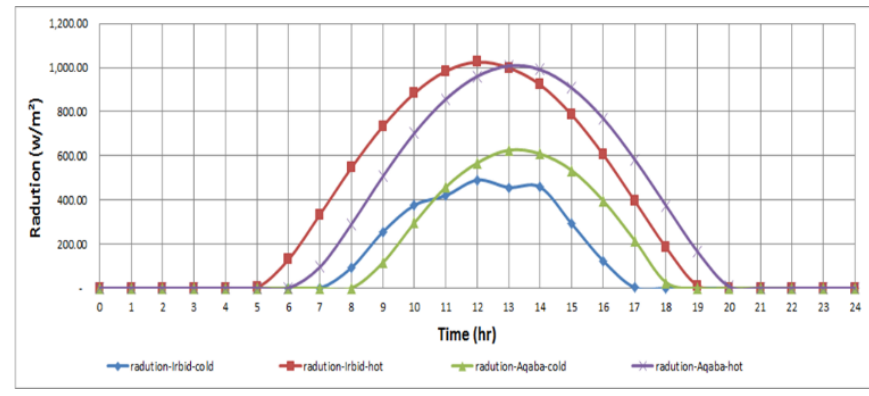

Figure 3. The radiation of the hot and cold climate of Irbid and Aqaba

\subsection{Outlet temperature of collector}

The outlet temperatures were monitored through the temperature controller. The outlet temperatures $\left(\left(\mathrm{T}_{\mathrm{O}}\right)\right.$ of the FPC on the same day for the hot climate in Irbid and Aqaba city are shown in Figure 4. The outlet temperatures of the $1^{\text {st }}$, $2^{\text {nd }}, 3^{\text {rd }}$ collector in Irbid city are $63^{\circ} \mathrm{C}, 78^{\circ} \mathrm{C}$ and $92^{\circ} \mathrm{C}$, respectively. While the outlet temperatures of collectors in Aqaba city for hot climate are $65^{\circ} \mathrm{C}, 81^{\circ} \mathrm{C}$ and $95^{\circ} \mathrm{C}$ of the $1^{\text {st }}$, $2^{\text {nd }}, 3^{\text {rd }}$ collector, respectively. Figure 5 shows the ETC for hot climate in Irbid and Aqaba city. It is clear that, the outlet temperatures in Irbid are $65^{\circ} \mathrm{C}, 96^{\circ} \mathrm{C}$ and $128^{\circ} \mathrm{C}$ for $1^{\text {st }}, 2^{\text {nd }}, 3^{\text {rd }}$ collector respectively.in Aqaba are $64^{\circ} \mathrm{C}, 94^{\circ} \mathrm{C}$ and $125^{\circ} \mathrm{C}$ for $1^{\text {st }}, 2^{\text {nd }}, 3^{\text {rd }}$ collector respectively. It can be seen that the outlet temperatures of FPC for a hot climate in Aqaba are higher than the ones in Irbid, Meanwhile, for hot climate the outlet temperatures of ETC in Irbid are a higher than in Aqaba. This is due to higher solar radiation in Irbid under hot climate condition and because of higher levels of humidity in Aqaba. The outlet temperature from ETC shows a fluctuation behavior, this behavior can be attributed to the reduced thermal loss along with constant optical losses from the ETC.

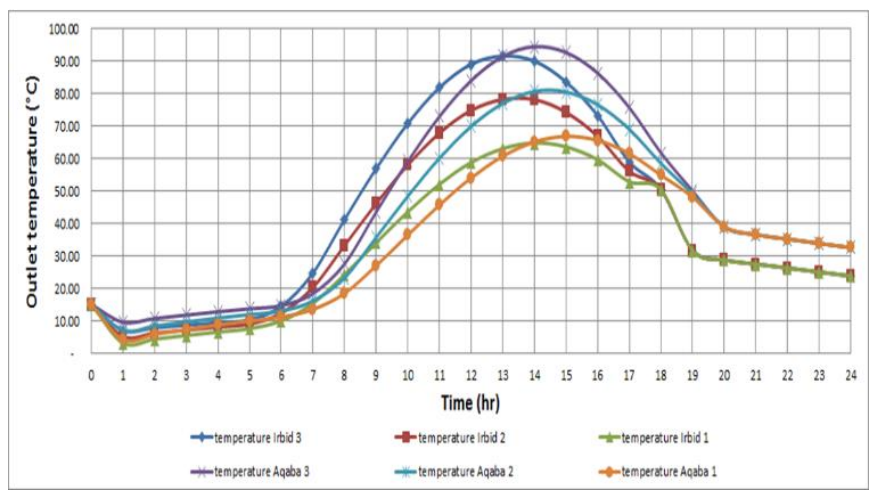

Figure 4. Outlet temperatures of FPC in Irbid and Aqaba for a typical day in June / hot climate

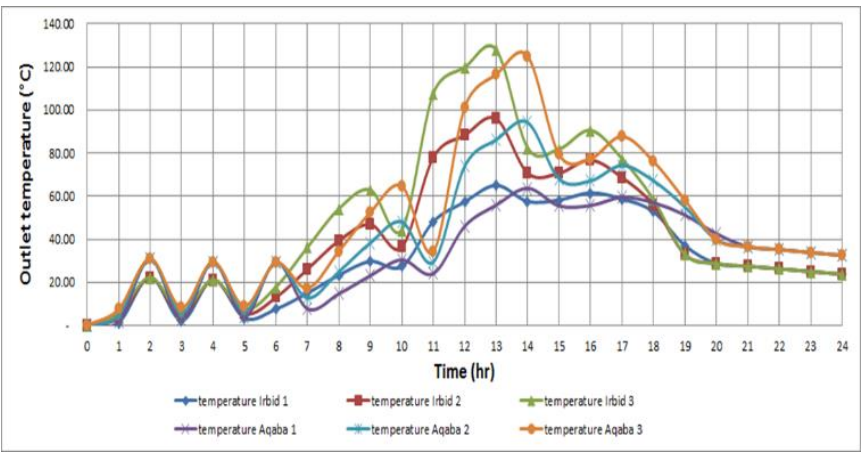

Figure 5. Outlet temperatures of ETC in Irbid and Aqaba for a typical day in June / hot climate

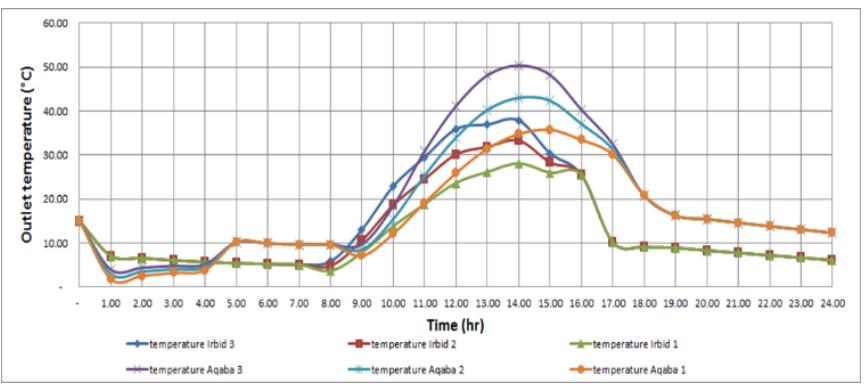

Figure 6. Outlet temperatures of FPC in Irbid and Aqaba for a typical day in January for cold climate

Figure 6 illustrates the outlet temperature $\left(\mathrm{T}_{\mathrm{O}}\right)$ of the FPC in Irbid city and Aqaba city for a typical day in January for the cold climate. OTs of $1^{\text {st }}, 2^{\text {nd }}$, and $3^{\text {rd }}$ collector in Irbid are $28^{\circ} \mathrm{C}$, $33^{\circ} \mathrm{C}$ and $38^{\circ} \mathrm{C}$, respectively. Meanwhile, the outlet temperature in Aqaba city are $35^{\circ} \mathrm{C}, 43^{\circ} \mathrm{C}$ and $50^{\circ} \mathrm{C}$ for $1^{\text {st }}, 2^{\text {nd }}$, and $3^{\text {rd }}$ collector, respectively. Figure 7 presents the outlet 
temperature $\left(\mathrm{T}_{\mathrm{O}}\right)$ of the ETC in Irbid city and Aqaba city for a typical day in January for the cold climate. The outlet temperature of the $1 \mathrm{st}, 2^{\text {nd }}$, and $3 \mathrm{e}^{\mathrm{d}}$ collector are $31^{\circ} \mathrm{C}, 43^{\circ} \mathrm{C}$ and $54^{\circ} \mathrm{C}$ in Irbid city and $37^{\circ} \mathrm{C}, 52^{\circ} \mathrm{C}$ and $66^{\circ} \mathrm{C}$ in Aqaba city.

It can be seen that the outlet temperature for cold climate of the ETC are higher than temperature values compared to FPC. The advantages of evacuated tube collectors are observed mainly during colder periods, which allows for a steadier thermal energy production.

The outlet temperature in Irbid city is higher than the ones in Aqaba city for ETC in a hot climate, meanwhile, outlet temperature in Aqaba city is higher than the outlet temperature values in Irbid in a cold climate for both FPC and ETC and in a hot climate for FPC too. In addition it can noted that except for the collector type as an effective factor, the outlet temperature depends on the intensity of solar energy and the period of a sunshine period as shown in Figures 4, 5, 6, and 7 this consistent with what reported by [14].

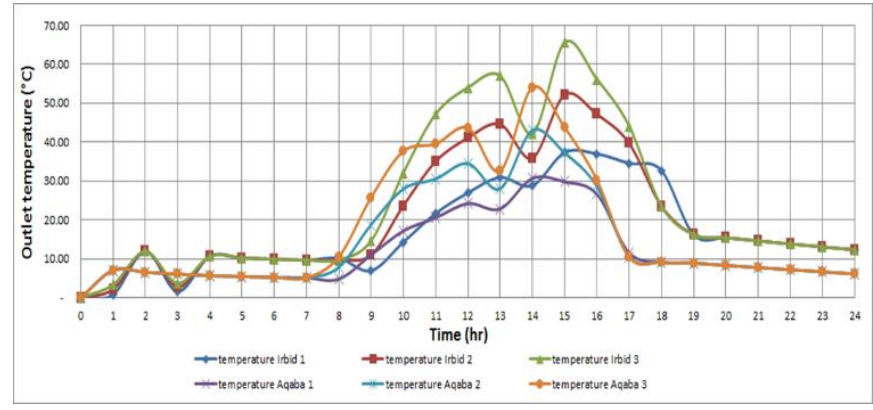

Figure 7. Outlet temperatures of ETC in Irbid and Aqaba for a typical day in January for cold climate

\subsection{Useful energy gain}

The performance of a solar collector can be estimated by an energy balance equation including the incident solar energy $\left(E_{\text {sun }}\right)$, optical and thermal losses $\left(\mathrm{Q}_{\text {loss }}=\mathrm{Q}_{\text {loss, Opt }}+\mathrm{Q}_{\text {Loss, th }}\right)$ and the useful energy gain $\mathrm{Qu}$.

The energy balance equation for a solar thermal collector can be written as

$$
E_{\text {sun }}+Q_{u}^{\text {in }}=Q_{u}^{\text {out }}+Q_{\text {loss }}
$$

The useful energy for the solar collector can be calculated by the heat carried by the working fluid

$$
Q_{u}=Q_{u}^{\text {in }}-Q_{u}^{\text {out }}=m \times C_{p} \times\left(T_{\text {out }}-T_{\text {in }}\right)
$$

where, $\mathrm{m}$ is the mass flow rate of the working fluid, $\mathrm{C}_{\mathrm{p}}$ is the specific heat, $\mathrm{T}_{\text {out }}$ and $\mathrm{T}_{\text {in }}$ are the outlet and inlet temperatures respectively.

The useful energy gain for FPC and ETC in Irbid and Aqaba city for a typical day in January for the hot climate is shown in Figures 8 and 9, respectively.

Figures 10 and 11 illustrate the useful energy gain of cold climate for FTC and ETC, respectively. According to Figures 8 to 12 , the useful energy gain of the 1 st collector is more than the 2 nd and the 3rd for both FPC and ETC. The increase in the inlet temperature leads to a decrease in the gain of energy, this confirmed with the results reported by Kasaeian et al. [19]. The results show that the useful energy gain of ETC is greater than of FPC; also, for both FPC and ETC, the useful energy gain of cold climate is less than hot climate.

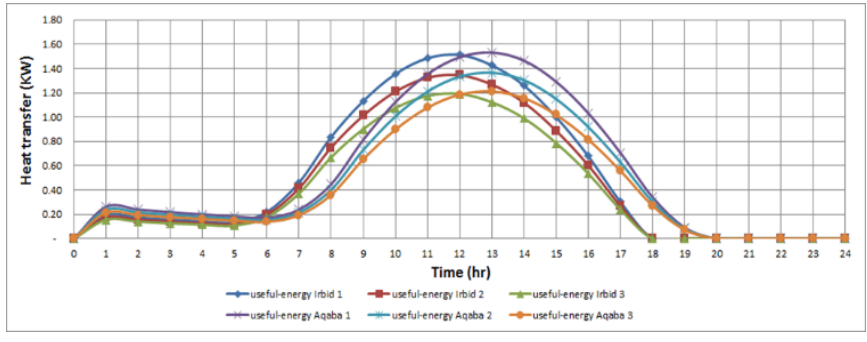

Figure 8. Useful energy gain for FPC in Irbid and Aqaba for a typical day in June for hot climate

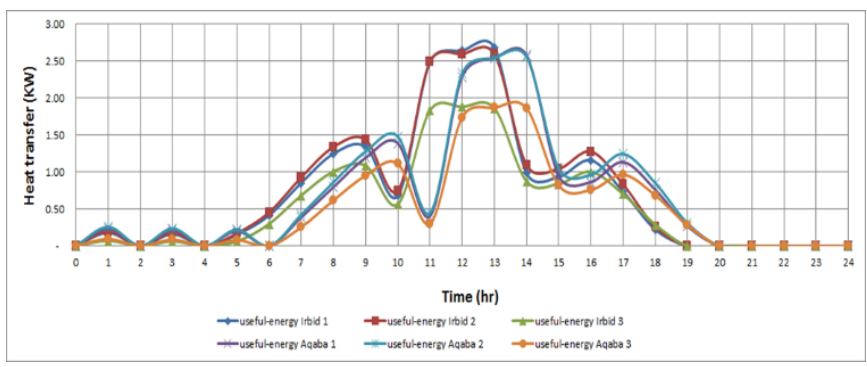

Figure 9. Useful energy gain for ETC in Irbid and Aqaba for a typical day in June for hot climate

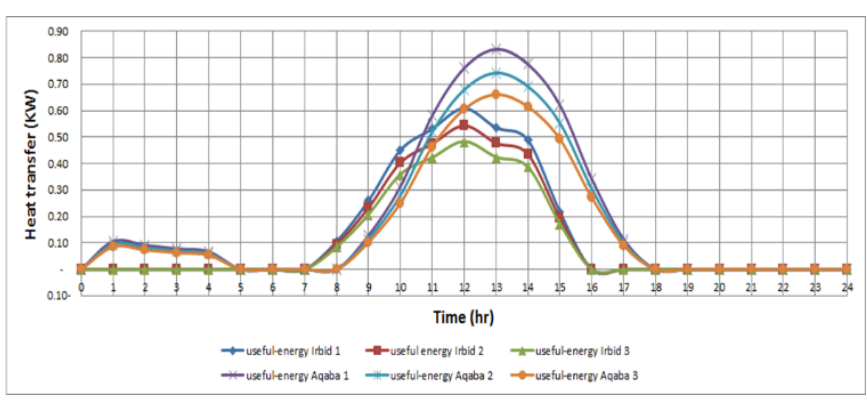

Figure 10. Useful energy gain for FPC in Irbid and Aqaba for a typical day in January for cold climate

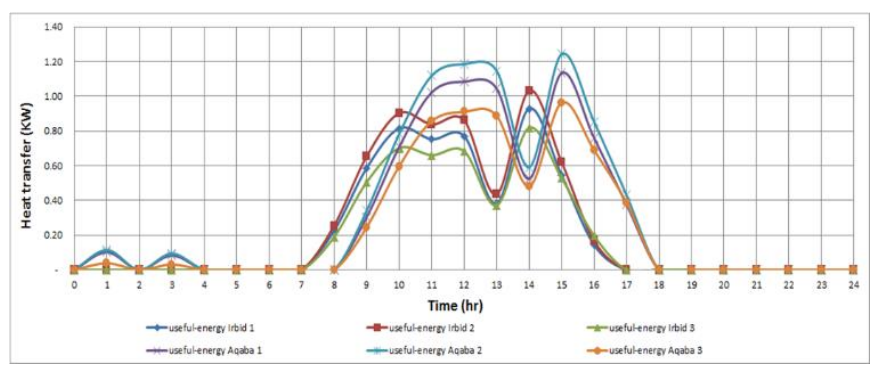

Figure 11. Useful energy gain for ETC in Irbid and Aqaba for a typical day in January for cold climate

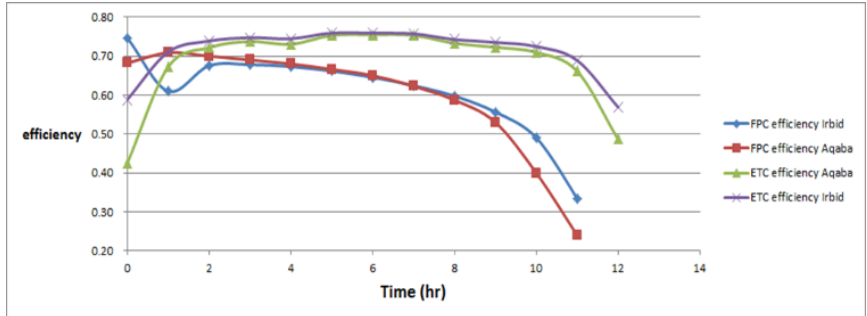

Figure 12. The efficiency of FPC and ETC for a typical day in June for hot climate in Aqaba and Irbid city

These results are confirmed with Kong et al. [18], they conducted a theoretical analysis and an experimental 
verification by applying a dynamic and a standard method, and they concluded that the heat transfer of ETC is more complicated than FPC. This investigation also reinforced with what was reported by the other studies [13]. Also, it agrees with Ayompe et al. [17], they reported that ETC generates higher energy than FPC.

\subsection{Collectors thermal efficiency}

The solar collector efficiency is related to the useful energy of the collector $\left(Q_{u}\right)$ and the solar radiation energy $(\mathrm{G})$. The efficiency of the collector can be expressed as the following:

$$
\begin{gathered}
\eta=\eta_{o}-\frac{a_{1}\left(T_{i n}-T_{a}\right)}{G}-\frac{a_{2}\left(T_{i n}-T_{a}\right)^{2}}{G} \\
\eta=\frac{Q_{u}}{A_{C} G}
\end{gathered}
$$

where, $a_{1}$ and $a_{2}$ are the coefficients, and both are for FPC greater than ETC, $T_{a}$ is the ambient temperature, $T_{i}$ is the working fluid inlet temperature, $\mathrm{G}$ is the solar radiation intensity and $\eta_{\mathrm{o}}$ is the collector efficiency at the standard conditions. Figures 12 and 13 illustrate the thermal efficiency of FPC and ETC for hot and cold climate in Irbid and Aqaba city, respectively. As mentioned before, decreasing the inlet temperature leads to increase the collector thermal efficiency, this behavior is clear from equation 3 . It is obvious that the thermal efficiency of ETC is greater than thermal efficiency FPC This behavior can be attributed to reduced thermal loss in the case of ETC. For hot climate the thermal efficiency of both collector are higher under Irbid climate conditions. This trend can be explained by the fact that the solar radiation in hot climate for Irbid city is greater that of Aqaba city, due to the high humidity in the coastal city of Aqaba (as shown in Fig. 12). On the other hand, the thermal efficiency of FPC is higher under Aqaba city compared to Irbid and the thermal efficiency of ETC are almost the same for the two cities Figure 13 shows the variation of the efficiency of FPC and ETC for a typical day in January for cold climate in Aqaba and Irbid city. It is clear that, the efficiency of Aqaba higher when using FPC, while Irbid is slightly higher when using ETC. This behavior can be attributed to the cold climate of Irbid which leads to high heat loss from the FPC compared to the ETC. While the hot climate in Aqaba reduces the heat loss from the PTC.

These results confirmed by Ayompe et al. [17], they reported that ETC generates energy higher than generated by FPC. This simulation is validated with experimental and numerical studies in Hong Kong city which have been conducted by Chow et al. [8]. Furthermore, agrees with the comparison that was reported in reference [19].

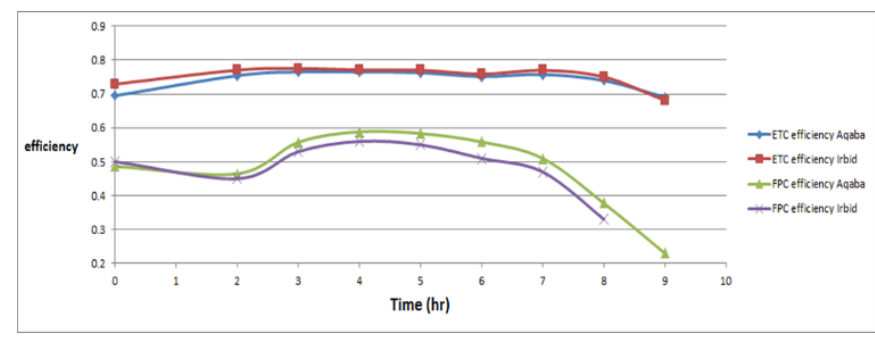

Figure 13. The efficiency of FPC and ETC for a typical day in January for cold climate in Aqaba and Irbid city

\section{CONCLUSIONS}

This study presents a theoretical investigation of thermal performance of Flat Plate Collector (FPC) and Evacuated Tube Collector (ETC) under the climate condition of two Jordanian cities. A transient simulation software TRANSYS16 has been used to evaluate the thermal performance for 24 hours in Irbid and Aqaba city, Jordan, in both hot and cold climate ( $21^{\text {st }}$ January and $21^{\text {st }}$ June). The results showed that the irradiation in the hot climate is higher than the cold climate. Irbid's irradiation is higher than Aqaba's in the hot climate and vice versa in the cold climate. In hot the climate, the outlet temperatures of the ETC are higher than of the FPC. Also, we observed that the performances of FPC and ETC systems in the cold climate are lower than the hot climate. The inlet temperature and the climatic characteristics are more effective on the FPC than the ETC collector. The ETC can be operated at higher temperatures application than FTP as a result of low loss by conduction and convection in ETC. On the other hand, both of the ETC and FPC efficiency are higher at low incidence angles. In the high load application, which required more than one collector; the results of this simulation showed that the useful energy gain of the $1^{\text {st }}$ collector is greater than the other following collectors. Further research work in needed to examine the exergy and thermo-economic characteristics of these solar collectors.

\section{REFERENCES}

[1] Rabl, A. (1985). Active Solar Collectors and Their Applications. Oxford University Press.

[2] Morrison, G.L., Budihardjo, I., Behnia, M. (2005). Measurement and simulation of flow rate in a water-inglass evacuated tube solar water heater, Solar Energy, $78(2)$ :

257-267. https://doi.org/10.1016/j.solener.2004.09.005

[3] Morrison, G.L. (2004). Budihardjo, I., Behnia, M., Water-in-glass evacuated tube solar water heaters. Solar Energy, 76(1-3): https://doi.org/10.1016/j.solener.2003.07.024

[4] Morrison, G.L., Ranatunga, D.B.J. (1980). Thermosyphon circulation in solar collectors. Solar Energy, 242: 191-198. https://doi.org/10.1016/0038092X (80)90392-8

[5] Ayompe, L.M., Duffy, A., McCormak, S.J., Conlon, M. (2011). Validated TRNSYS model for forced circulation solar water heating systems. Applied Thermal Engineering, 313(8-9): 1536-1542. https://doi.org/10.1016/j.applthermaleng.2011.01.046

[6] Budihardjo, I., Morrison, G.L., Behnia, M. (2007). Natural circulation flow through water-in-glass evacuated tube solar collectors. Solar Energy, 81(1): 1460-1472. https://doi.org/10.1016/j.solener.2007.03.002

[7] Budihardjo, I., Morrison, G.L. (2009). Performance of water-in glass evacuated tube solar water heaters. Solar Energy, 83(1): 49-56. https://doi.org/10.1016/j.solener.2008.06.010

[8] Chow, T.T., Dong, Z., Chan, L.S., Fong, K.F., Bai, Y. (2011). Performance evaluation of evacuated tube solar domestic hot water systems in Hong Kong, Energy and Buildings, $\quad 43(12)$ : 3467-3474. https://doi.org/10.1016/j.enbuild.2011.09.009 
[9] Hayek, M., Assaf, J., Lteif, W., (2011). Experimental investigation of the performance of evacuated-tube solar collectors under Eastern Mediterranean climatic conditions. Energy Procedia., 6: 618-626. https://doi.org/10.1016/j.egypro.2011.05.071

[10] Hobbi, A., Siddiqui, K. (2009). Optimal design of a forced circulation solar water heating system for a residential unit in cold climate using TRNSYS. Solar Energy, 83(5): 700-714. https://doi.org/10.1016/j.solener.2008.10.018

[11] Perers, B. (1988). Comparison of thermal performance for flat plate and evacuated tubular collectors. Journal of Advances in Solar Energy Technology, 1.1: 615-619. https://doi.org/10.1016/B978-0-08-034315-0.50118-X

[12] Morrison, G.L., Budihardjo, I., Behnia, M. (2004): Water-in-glass evacuated tube solar water heaters. Journal of Solar Energy, 761(3): 135-140. https://doi.org/10.1016/j.solener.2003.07.024

[13] Gunwale, O.A. (2006). Flat Plate Collector Solar Cooker. Department of Mechanical Engineering, Federal University of Technology, Nigeria, 9(3): 199-202.

[14] Struokmann, F. (2008). Analysis of a Flat-plate Solar Collector. Dept. of Energy Science, Faculty of Engineering, Lund University, Project Report, Sweden.

[15] Sekhar, Y.R., Sharma, K.V., Rao, M.B. (2009). Evaluation of Heat Loss Coefficients in Splar Flat Plate Collectors. ARPN Journal of Engineering and Applied Sciences,4(4).

[16] Druck, H., Heidemann, W., Muller-Steinhagen, H. (2004). Comparison test of thermal solar systems for domestic hot water preparation and space heating. Proceedings of EuroSun, Freiburg, Germany. https://doi.org/10.1016/j.rser.2019.06.048

[17] Ayompe, L.M., Duffy, A., McKeever, M., Conlon, M., Mc Cormack, S.J. (2011). Comparative field performance study of flat plate and heat pipe evacuated tube collectors ETCs for domestic water heating systems in a temperate climate. Journal of Energy, 36(5): 33703378. https://doi.org/10.1016/j.energy.2011.03.034

[18] Kong, W.Q., Wang, Z., Fan, J., Perersb, B., Chen, Z., Furbo, S., Andersen, E. (2012). Investigation of thermal performance of flat plate and evacuated tubular solar collectors according to a new dynamic test method. Journal of Energy Procedia, 30: 152-161. https://doi.org/10.1016/j.egypro.2012.11.019

[19] Kasaeian, A.B., Mohammadkarim, A., Sokhansefat, T., Alayi, R. (2015). Performance investigation of the yearly efficiency and solar fraction in vacuum tube solar collector using TRNSYS in Tehran. Journal of Current Research in Science, 3(5): 92-104. https:/www.researchgate.net/publication/263849724

[20] Remlaoui, A., Nehari, D., Elmeriah, A., Laissaoui, M. (2017). A TRNSYS model of a direct contact membrane distillation (DCMD) system coupled to a flat plate solar collector (FPC). Journal Européen des Systèmes Automatisés, JESA, 50(4-6): 335-360. https://doi.org/10.3166/JESA.50.335-360

[21] Tang, R., Yang, Y., Gao, W. (2011). Comparative studies on thermal performance of water-in-glass evacuated tube solar water heaters with different collector tilt-angles. Solar Energy, 85(7): 1381-1389. https://doi.org/10.1016/j.solener.2011.03.019

[22] Tang, R., Gao, W., Yu, Y., Chen, H. (2009). Optimal tiltangles of all glass evacuated tube solar collectors. Energy, 34(9): https://doi.org/10.1016/j.energy.2009.06.014 1387-1395.

[23] Kumar, A., Said, Z., Bellos, E. (2020). An up-to-date review on evacuated tube solar collectors. Journal of Thermal Analysis and Calorimetry, 136 (1): 1-17. https://doi.org/10.1007/s10973-020-09953-9

[24] Siuta-Olcha, A., Cholewa, T., Dopieralska-Howoruszko, K. (2020). Experimental studies of thermal performance of an evacuated tube heat pipe solar collector in Polish climatic conditions. Environ Sci Pollut Res. https://doi.org/10.1007/s11356-020-07920-3

[25] Olczak, P., Matuszewska, D., Zabagło, J. (2020). The comparison of solar energy gaining effectiveness between flat plate collectors and evacuated tube collectors with heat pipe: Case study. Energies, 13(7): 1829. https://doi.org/10.3390/en13071829

[26] Greco, A., Gundabattini, E., Gnanaraj. D.S., Masselli, C. (2020). A comparative study on the performances of flat plate and evacuated tube collectors deployable in domestic solar water heating systems in different climate areas. Climate, $8(6)$ : 78 . https://doi.org/10.3390/cli8060078

[27] Issa Etier, I., Al Tarabsheh, A., Ababne, M. (2010). Analysis of Solar Radiation in Jordan, Jordan Journal of Mechanical and Industrial Engineering, 6(4): 733-738.

[28] Baniyounes, A.M., (2017). Renewable energy potential in Jordan. International Journal of Applied Engineering Research, 12(19): 8323-8331.

[29] Hirsch, T.S.V. (2019). Assessing the feasibility of a solar water heating system in rural Uganda. Master's thesis faculty environmental sciences and natural resource management, Norwegian University of life sciences. https://doi.org/10.1016/j.solener.2010.04.020

[30] TRNSYS. TRNSYS 16 (2006). A transient system simulation program. The Solar Energy Laboratory, University of Wisconsin-Madison, Madison, U.S.A.

\section{NOMENCLATURE}

Ac
Cp
G
Qloss
Qloss, Opt
QLoss, th
Qu
Ta
Ti
To
$\eta$
ๆo

Collector Area $\left(\mathrm{m}^{2}\right)$

Specific heat (kJ/kg.K)

Solar radiation intensity $\left(\mathrm{W} . \mathrm{m}^{2}\right)$

Total energy loss $(\mathrm{kW})$

Optical energy loss (kW)

Thermal energy loss $(\mathrm{kW})$

Useful energy $(\mathrm{kW})$

Ambient temperature $\left({ }^{\circ} \mathrm{C}\right)$

Inlet temperature $\left({ }^{\circ} \mathrm{C}\right)$

Outlet temperature $\left({ }^{\circ} \mathrm{C}\right)$

Collector thermal efficiency

Collector thermal efficiency at the standard conditions 